\title{
BEHAVIOUR OF MINE WASTE AS REINFORCED SOIL
}

\author{
Sumitra S. Kandolkar ${ }^{1}$, J. N. Mandal ${ }^{2}$ \\ ${ }^{1,2}$ Research Scholar, Professor, Civil Engineering Department, Indian Institute of Technology Bombay, \\ Powai, Mumbai-400076, Maharashtra,India,10404806@iitb.ac.in, cejnm@civil.iitb.ac.in
}

\begin{abstract}
Mining in Goa is done by open cast method, which gives rise to huge quantity of mining waste that occupies space and forms a source for series of problems. The enomerous amount of mine waste dumped around the regions of mining activity need to be reused constructively. Hence, if the mine waste is studied for its use as a reinforced soil, then burning issue of environmental pollution caused by mining dumps lying unprotected and unstabilized can be tackled to a certain extent. Also, it will be a step towards finding an alternative material for cohesionless soil in reinforced soil construction. In this study an attempt is made to check the suitability of soil from one of the mining dumps in Goa to be used as reinforced soil. The mine waste soil samples are studied for its compressive strength and shear strength behaviour by conducting two types of tests, unconfined compressive strength test and triaxial tests on unreinforced and reinforced soil samples. The reinforcement used in the form of a grid made from natural material bamboo. The bamboo grid reinforcement is placed in one, two and three layers, for studying the effect of reinforcement on compressive strength, shear strength parameters, stiffness and modes of failure of mining waste soil. The results of the tests on mining waste show improvement in strength as a reinforced soil mass.
\end{abstract}

Index Terms: Mine waste, bamboo reinforcement, unconfined compression strength and triaxial tests

\section{INTRODUCTION}

Mine waste dumps have caused severe damage to the ecology and hydrology of the tiny state of Goa. As per the report of Goa State Pollution Control Board [10] there are 316 mining dumps spread across the mining active regions of the state, resulting in accidents such as slipping into and destroying paddy fields, silting up rivers including those supplying drinking water. Agriculture and horticulture all over the mining belt in the state has been severely hit by mining dumps. Due to decades of extraction of minerals, many mines are unable to store dumps within their mining lease, due to huge collection of substandard ore, rejects and overburden [8]. There is a need to put the mine waste to constructive use. Many researchers have attempted to study the stress-strain behaviour of cohesionless soil using triaxial tests [5], [15], [17]. Cohesive soil has also been considered for reinforced soil construction [11], [13]. However very limited research work is available on mine waste as an alternative material for reinforced soil construction. Cohesive soils with appropriate compaction also behave as good as granular soil with reinforcement and they can be used as an alternative material for soil wall construction [3]. Over the years strengthening of soil is done with variety of reinforcements which include natural geosynthetics made from jute, coir, bamboo in consolidation of soil [4], improving bearing capacity of soft soils, [15], as general soil reinforcement material [7].

The present study uses the combination of mine waste and bamboo grid as reinforcement to study the shear strength behaviour of soil under unconfined compression and triaxial loading conditions, so as to explore the use of mine waste from one particular region of Goa as alternative material for reinforced soil construction.

\section{CHARACTERIZATION OF MATERIALS}

\subsection{Mine Waste}

Mine waste soil obtained from the mining dumps at Advalpal village in Goa is considered for use as reinforced soil. The physical properties of the mine waste soil samples obtained from mining dumps are given in Table-1. The electrochemical property $\mathrm{pH}$ of mining waste is determined to be 5.48 . Representative sample of mine waste soil is shown in Fig-1

Table -1: Physical properties of mine waste soil

\begin{tabular}{|c|c|}
\hline Property & Value \\
\hline Specific gravity, $\mathrm{G}$ & 2.625 \\
\hline Liquid Limit, $\mathrm{W}_{\mathrm{L}}(\%)$ & 37.80 \\
\hline Plastic Limit, $\mathrm{W}_{\mathrm{P}}(\%)$ & 32.36 \\
\hline Plasticity Index, $\mathrm{I}_{\mathrm{P}}(\%)$ & 5.44 \\
\hline Effective particle size, $\mathrm{D}_{10}(\mathrm{~mm})$ & 0.0017 \\
\hline $\mathrm{D}_{30}(\mathrm{~mm})$ & 0.042 \\
\hline $\mathrm{D}_{60}(\mathrm{~mm})$ & 0.52 \\
\hline Uniformity Coefficient, $\mathrm{C}_{\mathrm{u}}$ & 305.88 \\
\hline Coefficient of curvature, $\mathrm{C}_{\mathrm{c}}$ & 1.995 \\
\hline Maximum dry unit weight, $\gamma_{\mathrm{dmax}}\left(\mathrm{kN} / \mathrm{m}^{3}\right)$ & 20.1 \\
\hline Optimum moisture content, $\mathrm{OMC}(\%)$ & $11.17 \%$ \\
\hline Coefficient of permeability, $\mathrm{k}(\mathrm{m} / \mathrm{sec})$ & $2.46 \times 10^{-06}$ \\
\hline
\end{tabular}




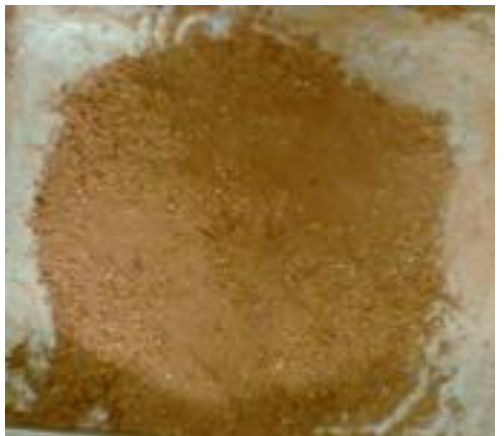

Fig-1: Mining waste soil sample

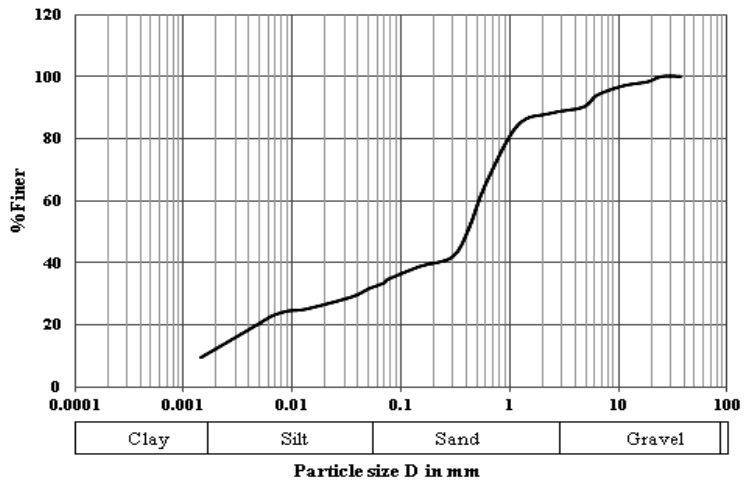

Fig -2 shows the grain size distribution curve for the soil. According to IS: 1498, 1970 [12], the mine waste soil is classified as silty sand.

Fig-2: Particle size distribution curve for mine waste soil

\subsubsection{Chemical Composition Of Soil}

The mine waste soil was tested for its chemical composition at the the Sophisticated Analytical Instrument Facility (SAIF), I.I.T., Bombay. X-Ray fluorescence test was performed by using a spectrometer (Philips PW 2404). The chemical composition of mining waste soil is given in Table-2.

Table -2: Chemical composition of mine waste

\begin{tabular}{|c|c|}
\hline Chemical Name & Value (\%) \\
\hline $\mathrm{SiO}_{2}$ & 27.782 \\
\hline $\mathrm{Al}_{2} \mathrm{O}_{3}$ & 10.441 \\
\hline $\mathrm{Fe}_{2} \mathrm{O}_{3}$ & 10.748 \\
\hline $\mathrm{CaO}$ & 0.004 \\
\hline $\mathrm{K}_{2} \mathrm{O}$ & 0.501 \\
\hline $\mathrm{MnO}$ & 0.052 \\
\hline $\mathrm{P}_{2} \mathrm{O}_{5}$ & 0.018 \\
\hline $\mathrm{SrO}(p p m)$ & 15.384 \\
\hline $\mathrm{TiO}_{2}$ & 1.449 \\
\hline
\end{tabular}

\subsection{Reinforcement}

Natural material bamboo is used as reinforcement. Bamboo strips are arranged to form a bamboo grid (BG), the grid is circular in shape with diameter 55 $\mathrm{mm}$ and aperture size $10 \mathrm{~mm} \times 10 \mathrm{~mm}$ as shown in

Fig-3.

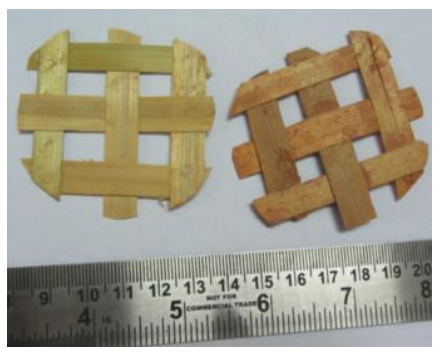

Fig-3: Bamboo grid

\subsubsection{Tensile Strength of Bamboo Grid}

The tensile strength of bamboo grid is evaluated by conducting wide width tension test. The test is performed as per ASTM D4595 [1]. Fig-4(a) (b) shows the bamboo grid in wide width tension test before and after failure respectively. Bamboo grid sample of size $200 \mathrm{~mm}$ wide x $100 \mathrm{~mm}$ gauge length was subjected to tensile pull. Fig-5 shows the load-strain curve of bamboo grid tension test. Table-3 gives the properties of bamboo used in the present study.
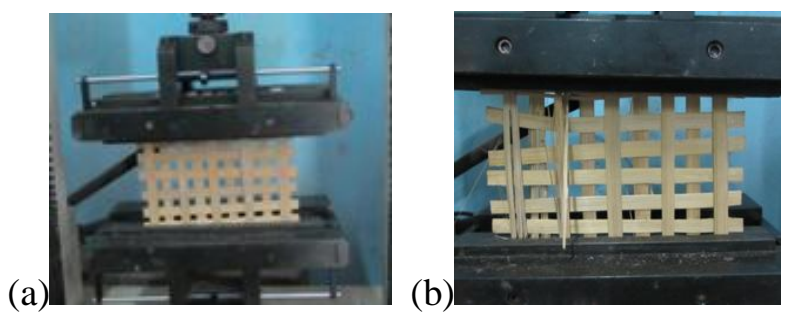

Fig-4: Bamboo grid in tension test (a) before failure, (b) after failure

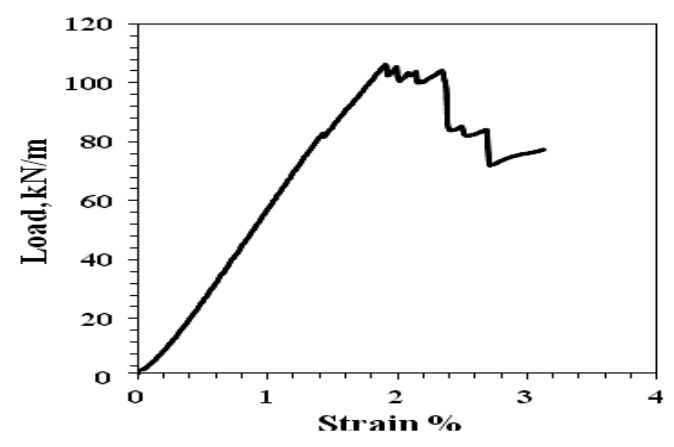

Fig-5: Load versus strain curve for bamboo grid sample Table -3: Properties of bamboo 


\author{
of sample height.
}

\begin{tabular}{|c|c|}
\hline Property & Value \\
\hline Mass per unit area $\left(\mathrm{gm} / \mathrm{m}^{2}\right)$ & 512.5 \\
\hline Tensile Strength $(\mathrm{kN} / \mathrm{m})$ & 106.37 \\
\hline Maximum elongation & $1.9 \%$ \\
\hline $\begin{array}{c}\text { Initial tangent modulus } \\
(\mathrm{kN} / \mathrm{m})\end{array}$ & 7142.85 \\
\hline
\end{tabular}

\title{
3 EXPERIMENTAL WORK
}

\subsection{Tests Conducted}

The mining waste soil is subjected to following types of tests to check the strength in unreinforced and reinforced case.

1) Unconfined Compression Strength (UCS) tests

2) Triaxial Tests (Unconsolidated Undrained, UU)

\subsubsection{Preparation Of Specimen}

Remoulded specimens are prepared in the laboratory depending on the proctors data at the required moulding water content. The sample size used was $75 \mathrm{~mm}$ diameter and 150 $\mathrm{mm}$ height, prepared in a split mould. The dry weight of soil (Wdsoil) required to prepare the specimen was calculated based on, Wdsoil $=\gamma d \max \times$ volume of the triaxial mould. The amount of water to be added was calculated by Wwater= Wdsoil $\times$ OMC. The dry soil and water is then mixed into a homogeneous mass.

For unreinforced sample the measured quantity of soil is put in the mould in layers and 25 blows are applied to each layer. Care is taken to obtain uniform degree of compaction. For the reinforced sample preparation the measured quantity of soil required to fill the triaxial mould was divided into equal portions based on the number of layers of reinforcement. The level of reinforcement position is marked on the mould and accordingly the soil is compacted up to the marking, then the compacted soil surface is scratched with the help of a pointed tool and the reinforcement is placed. Five types of samples were tested,

i. Unreinforced soil sample

ii. Reinforced soil sample with reinforcement at top and bottom

iii. Reinforced soil sample with reinforcement at the mid height of sample

iv. Reinforced soil sample with reinforcement at each 1/3rd of sample height and

v. Reinforced soil sample with reinforcement at each $1 / 4^{\text {th }}$

The soil density in each test was maintained constant. Confining pressures used were $50 \mathrm{kPa}, 100 \mathrm{kPa}$ and $150 \mathrm{kPa}$, so as to obtain the shear strength parameters and to simulate the different loading conditions in the field. Fig-6(a) to (e) shows the five soil samples considered in experimental plan.

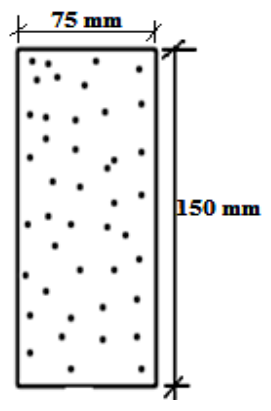

(a)

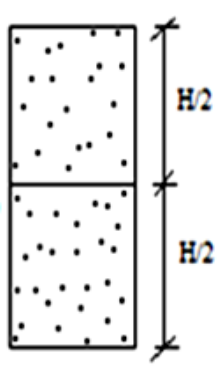

(c)

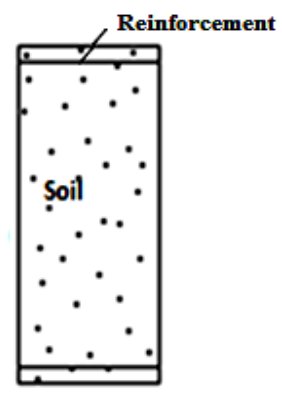

(b)

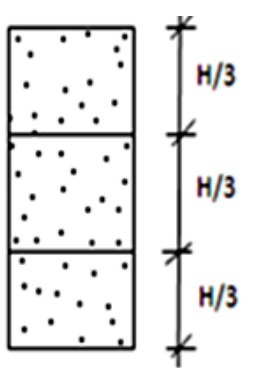

(d)

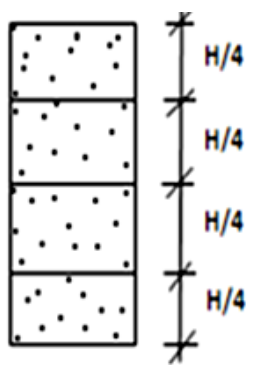

(e)
Fig-6: Triaxial test experimental plan of sample (a) unreinforced, (b) reinforced at top and bottom, c) reinforced at centre with single layer, (d) reinforced with two layers, (e) reinforced with three layers.

\subsubsection{Test Procedure}

The UCS test is conducted by placing the unreinforced or reinforced soil sample in the Perspex cell, without water in the cell, hence confining pressure on the soil sample is zero and the soil is made to fail under increasing normal pressure. The sample is sheared under constant volume.

The Unconsolidated Undrained (UU) triaxial tests were conducted as per Indian Standard IS 2720(part 11) - 1993 [12]. Fig-7 shows the triaxial test apparatus used for conducting the tests. The specimen was carefully extruded, weighed to check the desired density of compacted sample being attained, and immediately set up in the triaxial cell. The hydraulic confining pressure system was used to apply confining pressure simulating the effect of surrounding soil at that depth. A load cell and LVDT (Linear Variable Differential Transformer) is used to measure the deviator load and vertical displacement respectively through an electronic display system. The load 
cell and LVDT are calibrated before use. The strain rate was kept at constant rate of $1.2 \mathrm{~mm} /$ minute during testing.

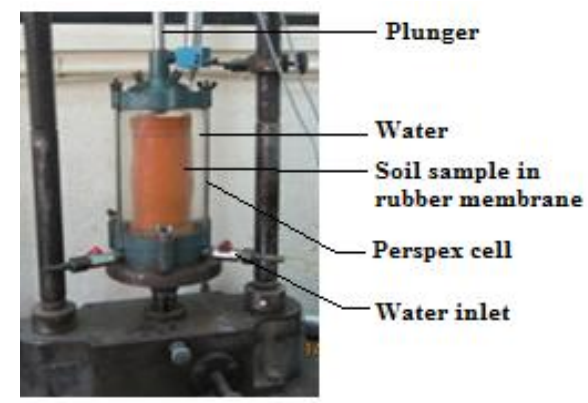

Fig-7: Triaxial test apparatus

The test is stopped when the deformation of the sample increases without any considerable increase in load. All the tests were conducted up to maximum axial strain of $20 \%$ to permit evaluation of the post peak stress-strain behaviour. However all samples failed prior to reaching $20 \%$ strain. The test was conducted to investigate the strength contribution made by bamboo reinforcement and the soil behaviour as reinforced soil under triaxial loading.

\section{RESULTS AND DISCUSSIONS}

\subsection{Unconfined Compressive Strength Test}

\subsubsection{Modes Of Failure}

Fig-8(a) to (e) shows the modes of failure of soil samples tested under unconfined compression. The failed samples show fine cracks on the sample surface inclined at approximate values of $45+\phi / 2$. Samples with two and three layers of reinforcement show longer cracks on the surface along with some amount of bulging.

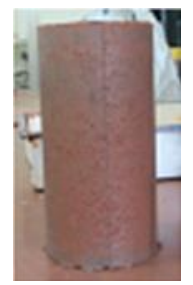

(a)

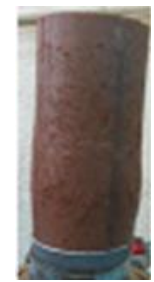

(b)

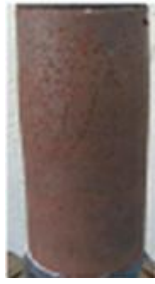

(c)

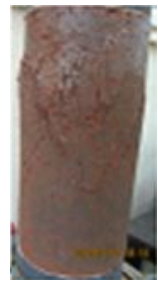

(d)

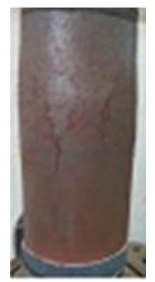

(e)
Fig-8: Modes of failure of soil sample: Unreinforced soil sample (a) before failure (b) after failure (c) Soil sample with reinforcement at centre (d) Reinforcement at each 1/3rd height of sample(two layers) and (e) Reinforcement at each 1/4th height of sample (three layers)

\subsubsection{Stress Strain Behaviour}

The stress-strain curves are shown in
Fig-9. The stress - strain curves show a well defined peak stress at failure and there is loss in post-peak stress values. Unreinforced soil samples reaches the peak stress value at axial strain of $2.26 \%$, whereas, the reinforced soil samples attain the peak shear strength value at axial strain of $2 \%$, hence reinforcement increases the stiffness of soil samples. The soil deformation mobilizes the shear strength in soil and peak strength of the soil increases with deformation until a peak shear stress value is attained. The peak shear stress value increases as the number of layers of reinforcement are increased from no reinforcement to three layers of reinforcement. Table- 4 gives the UCS and strain \% values corresponding to unreinforced and reinforced mine waste soil specimen.

Table-4: Unconfined compressive strength and strain values

\begin{tabular}{|c|c|c|}
\hline Type of specimen & UCS $(\mathrm{kPa})$ & strain \% \\
\hline Unreinforced soil & 298.67 & 2.26 \\
\hline Reinforced with BG, 1 layer & 366.97 & 2.00 \\
\hline Reinforced with BG, 2 layers & 430.34 & 2.00 \\
\hline Reinforced with BG, 3 layers & 488.01 & 2.00 \\
\hline
\end{tabular}

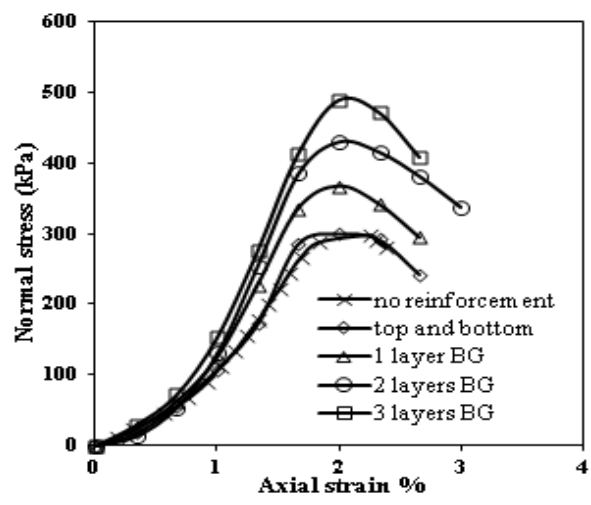

Fig-9: Stress-strain curves corresponding to unreinforced soil sample and samples reinforced at top and bottom, at centre, at

$1 / 3$ rd height and at $1 / 4$ th height of soil specimen

\subsection{Tri axial Test}

\subsubsection{Modes Of Failure}

The modes of failure of triaxial test specimen are shown in Fig-10(a), (b), (c). In case of unreinforced soil failed samples fine cracks were observed on the surface, whereas the reinforced soil samples failed by bulging. Bulging is more towards the central and bottom portion of the reinforced soil samples. Bulging of specimen indicates deformation of the soil and deformation mobilizes the shear strength of soil. Bulging is noticed to be more prominent for soil samples reinforced with three layers of bamboo grid. 
(a)

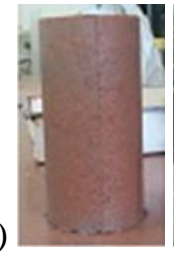

(i)

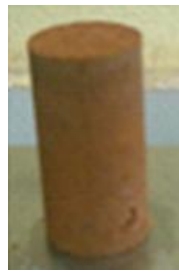

(i)

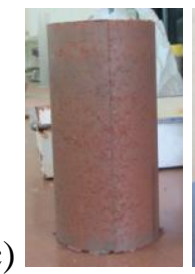

(i)

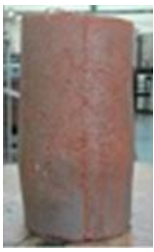

(ii)

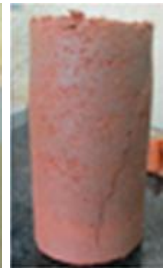

(ii)

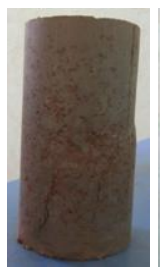

(ii)

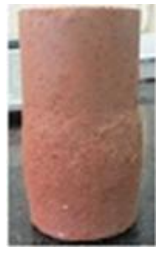

(iii)

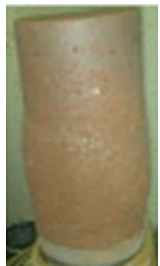

(iii)

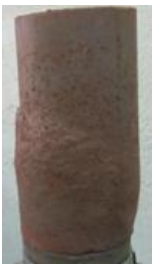

(iii)

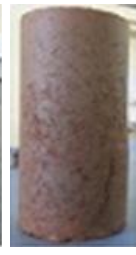

(iv)

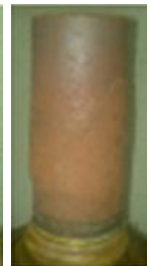

(iv)

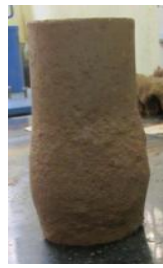

(iv)

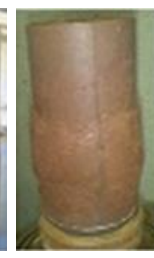

(v)

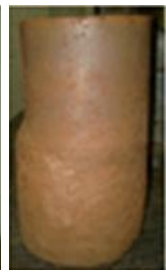

(v)

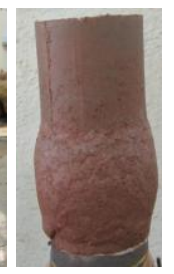

(v)
Fig-10: Modes of failure of soil sample at confining pressure (a) $50 \mathrm{kPa}$ (b) $100 \mathrm{kPa}$ and (c) $150 \mathrm{kPa}$ for soil as i)

Unreinforced soil sample before failure ii) after failure iii) reinforced sample after failure with reinforcement at centre iv) at each 1/3rd height of sample (two layers) and v) at each 1/4th height of sample (three layers)

\subsubsection{Stress Strain Behaviour}

The stress strain curves are shown in Fig-11(a), (b), (c). The unreinforced sample has the least deviator stress at failure and the sample with reinforcement at top and bottom shows a similar behaviour, the reinforced samples exhibit higher values of peak deviator stress and the deviator stress increases with the number of layers of reinforcement, the highest being for the sample with three layers of reinforcement.

The loss in post peak deviator stress is less in the triaxial tested samples as compared with the samples in unconfined compression strength tests. In triaxial test soil can sustain larger deformations due to confinement. It is noticed that after attaining maximum value of deviator stress there is not much change in the stress value. As seen in stress-strain curves of triaxial tests, axial strain \% corresponding to peak deviator of reinforced soil sample is lower than the axial strain \% corresponding to peak deviator stress of unreinforced soil; this indicates the stiffness of reinforced soil samples in triaxial tests.

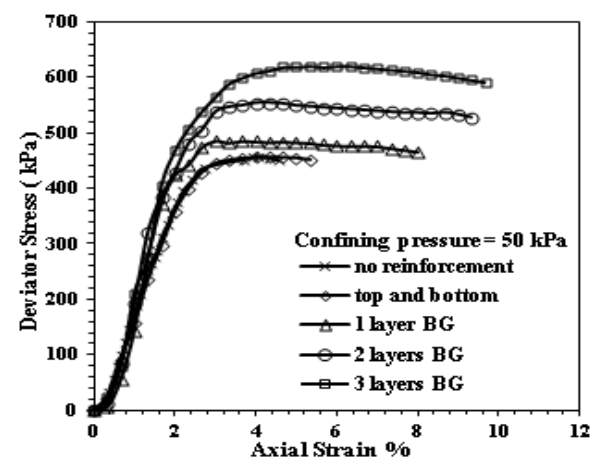

(a)

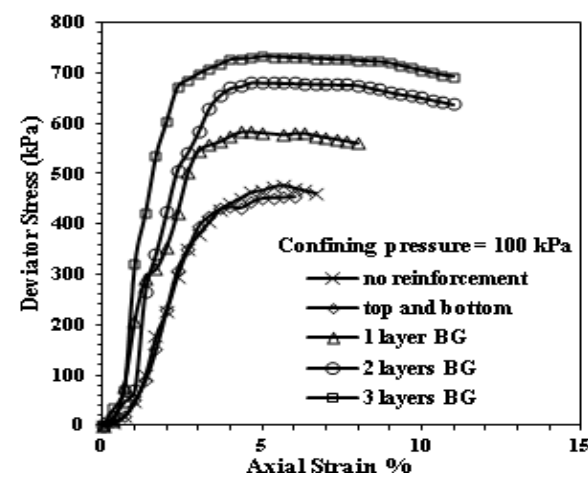

(b)

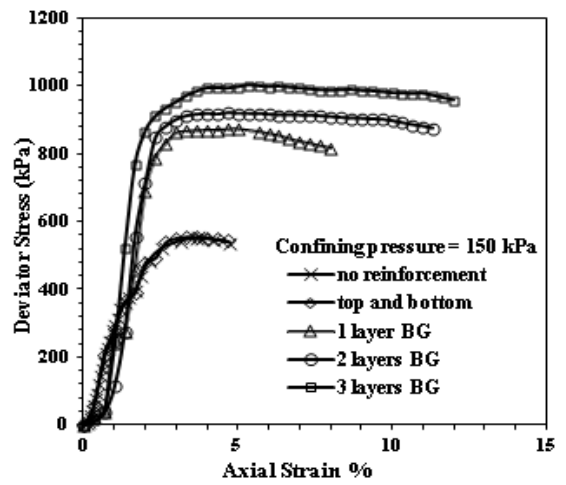

(c)

Fig-11: Deviator stress-strain relationship for unreinforced and reinforced soil samples at confining pressures of (a) $50 \mathrm{kPa}$ (b) $100 \mathrm{kPa}(\mathrm{c}) 150 \mathrm{kPa}$

\subsubsection{P-Q Diagrams And Shear Strength Parameters}

Fig-12 show the p-q diagram corresponding to unreinforced sample and samples reinforced with one, two and three layers of reinforcement. 


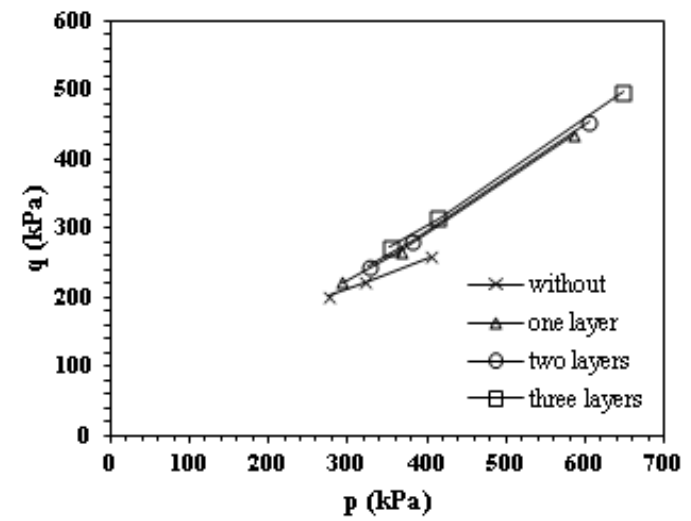

Fig-12: p-q diagram for the unreinforced and reinforced Samples

Table-5 lists the values of shear strength parameters of the unreinforced and reinforced soil samples based on the $\mathrm{p}-\mathrm{q}$ diagram.

Table-5: Shear strength parameters of unreinforced and reinforced soil samples with triaxial tests at confining pressures of $50 \mathrm{kPa}, 100 \mathrm{kPa}$ and $150 \mathrm{kPa}$

\begin{tabular}{|c|c|c|}
\hline Soil sample & C or $\mathrm{C}_{\mathrm{a}}(\mathrm{kPa})$ & $\begin{array}{c}\phi \text { or } \delta \\
\left({ }^{\circ}\right)\end{array}$ \\
\hline Unreinforced soil & 51.5 & 32 \\
\hline Reinforced with BG, 1 layer & 17.5 & 53 \\
\hline $\begin{array}{c}\text { Reinforced with BG, 2 } \\
\text { layers }\end{array}$ & 32.5 & 52 \\
\hline \multicolumn{2}{|c|}{$\begin{array}{c}\text { Reinforced with BG, 3 } \\
\text { layers }\end{array}$} & 45 \\
\hline $\begin{array}{l}\text { C } \text { Cohesion for unreinforced case } \\
\begin{array}{l}\mathrm{C} \text { a Adhesion for reinforced case } \\
\phi\end{array} \text { Angle of internal friction for unreinforced case } \\
\delta \quad \text { Friction angle for reinforced case }\end{array}$ \\
\hline \multicolumn{2}{|c|}{} \\
\hline
\end{tabular}

The shear strength parameter values indicate slippage failure of the bamboo reinforced mining waste, as the adhesion is decreasing and the interface friction angle is increasing as compared to the cohesion and friction angle of unreinforced soil mass.

\subsubsection{Effect Of Number Of Reinforcement Layers On}

\section{Peak Deviator Stress}

Effect of number of layers of reinforcement is shown in Fig13. Bamboo grid inclusion increases the peak deviator strength of mine waste significantly. Unreinforced sample has the least peak deviator stress. For reinforced sample with one layer at centre, the peak deviator stress increases by $5 \%$, with two

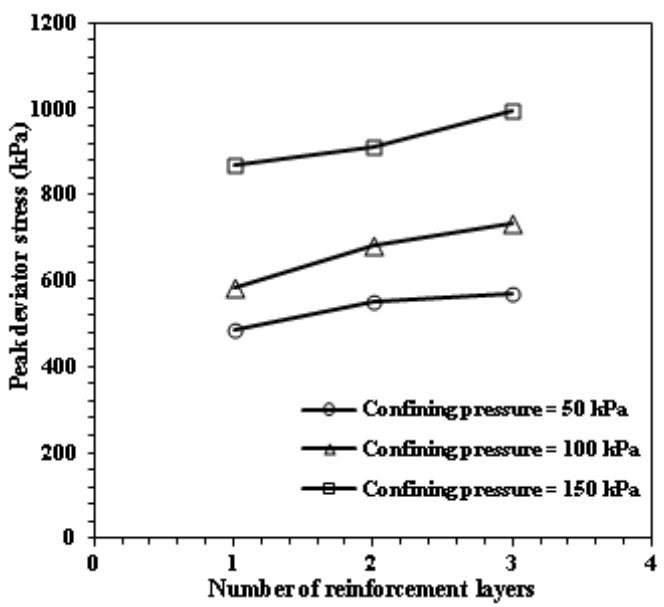

Fig-13: Effect of number of layers of reinforcement (bamboo grid) on the peak deviator stress

layers it increases by $19.4 \%$ and with three layers of reinforcement the peak deviator stress increases by $22.9 \%$ as compared to the peak deviator stress of unreinforced soil sample at a confining pressure of $50 \mathrm{kPa}$. For applied confining pressure of $150 \mathrm{kPa}$ the peak strength increases by $57.6 \%$, $64.5 \%$ and $80.2 \%$ as the number of reinforcement layers increase from one to three. Increase in peak shear strength is more pronounced for greater number of reinforcement layers. This indicates that the reinforcement improves the lateral confinement of the soil sample. The peak deviator stress values corresponding to all the test cases is given in Table- 6 .

Table-6: Peak deviator stress for unreinforced and reinforced soil samples with one, two and three layers of bamboo grid reinforcement.

\begin{tabular}{|c|c|c|c|}
\hline \multirow{2}{*}{$\begin{array}{c}\text { Type of soil } \\
\text { sample }\end{array}$} & $50(\mathrm{kPa})$ & $\begin{array}{c}\text { Peak deviator stress values } \\
(\mathrm{kPa})\end{array}$ & $\begin{array}{c}150 \\
(\mathrm{kPa})\end{array}$ \\
\cline { 2 - 4 } & 462.75 & 476.89 & 552.68 \\
\hline $\begin{array}{c}\text { Unreinforced } \\
\text { Reinforced with } \\
\text { BG, 1 layer }\end{array}$ & 486.02 & 582.80 & 870.94 \\
\hline $\begin{array}{c}\text { Reinforced with } \\
\text { BG, 2 layers }\end{array}$ & 552.53 & 682.27 & 908.96 \\
\hline $\begin{array}{c}\text { Reinforced with } \\
\text { BG, 3 layers }\end{array}$ & 608.25 & 734.72 & 995.81 \\
\hline
\end{tabular}

\subsubsection{Effect of Confining Pressure On The Peak}

\section{Deviator Stress}

The applied confining pressure improves the peak deviator stress, which is depicted in the Fig-14. The peak deviator stress of unreinforced sample increases as the applied confining 
pressure is increased from $50 \mathrm{kPa}$ to $150 \mathrm{kPa}$. The sample reinforced with one layer of bamboo grid at centre shows an increase of $5.03 \%, 22.2 \%$ and $57.58 \%$ in peak deviator stress at the confining pressure of 50,100 and $150 \mathrm{kPa}$ respectively. The inclusion of bamboo grid in mine waste soil shows an impact on improving the strength of the mining waste soil in conjunction with confining pressure.Table-7 brings out the comparison of the mine waste with the FHWA (2001) recommendations [9].

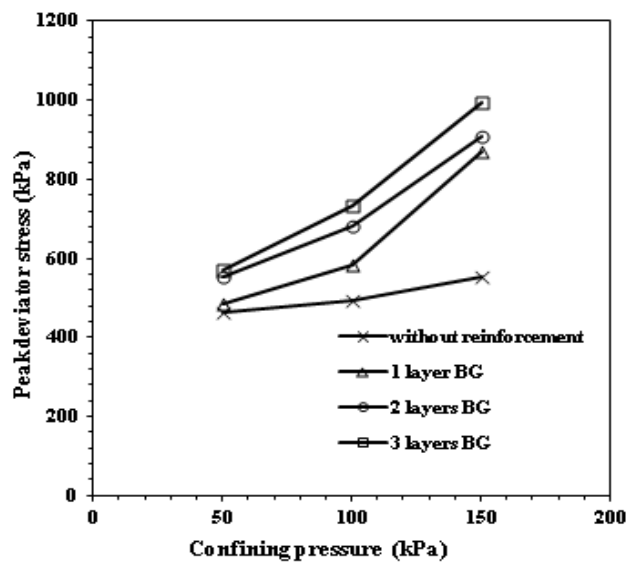

Fig-14: Effect of confining pressure on the peak deviator stress of unreinforced and soil sample reinforced with one, two and three layers of bamboo grid reinforcement

Table-7: Comparison of mine waste properties with FHWA (2001) recommendations

\begin{tabular}{|c|c|c|}
\hline Property of soil & $\begin{array}{c}\text { FHWA } \\
\text { recommendation }\end{array}$ & $\begin{array}{c}\text { Present study } \\
\text { result }\end{array}$ \\
\hline Plasticity Index, $\mathrm{I}_{\mathrm{p}}$ & Shall not exceed 6 & 5.44 \\
\hline $\begin{array}{c}\text { Angle of internal } \\
\text { friction, } \varphi\end{array}$ & $\begin{array}{c}\text { Lower bound value } \\
28^{\circ}\end{array}$ & $32^{\circ}$ \\
\hline Cohesion $(\mathrm{kPa})$ & Cohesionless & 51.5 \\
\hline $\begin{array}{c}\text { pH value } \\
\text { passing } 0.075 \\
\mathrm{~mm}\end{array}$ & $0-15$ & 5.48 \\
\hline
\end{tabular}

\section{CONCLUSIONS}

The mine waste soil is tested for its strength improvement as reinforced mass by using bamboo reinforcement. Based on the experimental findings, following conclusions are drawn,

1. The evaluated unconfined compressive strength of the bamboo reinforced mine waste soil was more as compared to the unreinforced sample and increases as the number of layers of reinforcement increased.

2. The peak stress value in UCS test for unreinforced case is reached at a strain value of $2.26 \%$, whereas for the reinforced case the peak deviator stress is reached at a strain of $2 \%$. Hence reinforced mine waste soil behaves stiffer than the unreinforced soil mass.

3. The UCS for unreinforced case was $298.67 \mathrm{kPa}$ and it increases to $366.97,430.34,488.01 \mathrm{kPa}$ for mine waste reinforced with one layer, two layers and three layers of reinforcement respectively.

4. Triaxial test results indicate shear strength improvement of mine waste soil with reinforcement as well as with confining pressure. The maximum strength improvement was with three layers of reinforcement at an applied confining pressure of $150 \mathrm{kPa}$.

5. The adhesion value of each of the reinforced case is less than the cohesion value of unreinforced case, whereas the angle of internal friction is increased by an average amount of $62.49 \%$ as compared to the unreinforced case.

6. The reinforcement enhances the confinement of the sample over and above the applied confining pressure, hence for a particular confining pressure the percentage increase in peak deviator stress is more with increasing confining pressure as compared to the percentage increase in peak deviator stress with number of layers of reinforcement at same confining pressure.

7. The grid structure of reinforcement being open structure allows strength mobilization at low stresses and further enhances the friction at the soil-reinforcement interface thereby increasing the shear strength of soil.

8. Hence, the abundant soil available as mine waste dumps at Advalpal village in Goa can be considered for its use as reinforced soil along with bamboo reinforcement.

\section{REFERENCES}

[1] ASTM D 4595-11, "Standard test method for tensile properties of geotextiles by the Wide-width strip method," American Society for Testing and Materials, Philadelphia, PA.

[2] ASTM D 5261. "Standard Test Method for Measuring Mass per Unit area of Geotextiles," American Society of Testing Materials, Philadelphia, PA.

[3] Bergado, D.T., Macatol, K.C., Amin, N.U., Chai, J.C., Alfaro, M.C. (1993). "Interaction of lateritic soil and steel grid reinforcement," Canadian Geotechnical Journal 30(2), 376-384.

[4] Bera, A. K. and Roy, A. (2012). "Engineering properties of jute geotextile and its efficacy to the consolidation of soil," Electronic Journal of Geotechnical Engineering, Vol. 17, 2631-2645.

[5] Broms, B. B. (1977). "Triaxial tests with fabric reinforced soil," International Conference on the, Use of Fabrics in Geotechnics, Paris, France, Vol. III, pp 129133.

[6] BS 8006 (1995) "Code of Practice for Strengthened/Reinforced Soils and other Fills," BSI, Milton Keynes, UK. 
[7] Datye, K R. (1988) "Proceedings of the International Symposium on Theory and Practice of Earth Reinforcement," Fukuoka, Kyushu, Japan, pp. 69-74.

[8] Draft Goa Mining Policy (Major Minerals), 2012.

[9] Elias, V. E., Christopher, B. R., and Berg, R. R. (2001) Federal Highway Administration (FHWA), "Mechanically Stabilized Earth Walls and Reinforced Soil Slopes Design and Construction Guidelines," Technical Report, FHWA-NHI-00-043, 394.

[10] Goa State Pollution Control Board Report under Central Government National Water Monitoring Program, 201011.

[11] Ingold, T. S.(1983a) "Reinforced clay subject to undrained triaxial loading," Journal of Geotechnical Engineering, ASCE, 109(5), pp. 738-744. IS 1498, Reaffirmed 2002 (1970). "Classification and identification of soils for general engineering purposes," Indian Standards, New Delhi, India, pp. 1-26.

[12] IS 2720(part 11), Reaffirmed 1997(1998), "Methods of tests for soils: Determination of shear strength parameters of a specimen tested in unconsolidated undrained triaxial compression without the measurement of pore water pressure," Bureau of Indian Standards (BIS), pp 1-6.

[13] Jewell, R. A., and Jones, C. J. F. P. (1981). "The reinforcement of clay soils and waste materials using grids," Proceedings of 10th International Conference 10th Soil Mechanics and Foundation Engineering, Stockholm, Sweden,3, 701-706.

[14] Parulekar, A. H., Ansari, Z. A., Ingole, B. S. (1986). "Effect of Mining Activities on the Clam Fisheries and Bottom Fauna of Goa Estuaries India," Proceedings of the Indian Academy of Sciences - Animal Sciences.

[15] Schlosser, F. and Long, N. T. (1974). "Recent results in French research on reinforced earth," Journal of Construction Division Proceedings ASCE, 100, No. CO3, pp 223-237.

[16] Toh, C. T., Chee, S. K., Lee, C. H., Wee, S. H. (1994). "Geotextile bamboo fascine mattress for filling over very soft soils in Malaysia," Geotextiles and Geomembranes, Vol. 13(6-7), pp 357-369.

[17] Zhang, M. X., Zhou, H., Javadib, A. A., and Wang, Z. W. (2007). "Experimental and theoretical investigation of strength of soil reinforced with multi-layer horizontal- vertical orthogonal elements", Geotextiles and Geomembranes, Vol. 26, Issue 1, pp 1-13.

\section{BIOGRAPHIES:}

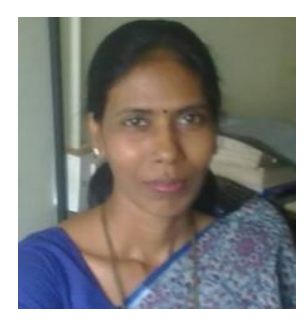

Sumitra S. Kandolkar, PhD Research Scholar, (Geotechnical Engineering), Department of Civil Engineering, Indian Institute of Technology Bombay, Powai, Maharashtra - India.
J. N. Mandal, Professor in Civil Engineering Civil Engineering Department, Indian Institute of Technology Bombay, Powai, Mumbai - 400076 Maharashtra, India. 